\title{
Grundtvigs rimbreve
}

\author{
Af Gustav Albeck
}

Det er et særpræg for Grundtvig, at hans digtning er gennemsyret af bevidst arkaiserende træk. Det gælder ordvalg og sprogformer, versemål og genrer. De følgende bemærkninger sigter mod at give en oversigtsmæssig udredning af hans forhold til en så speciel genre som rimbrevet.

Rimbrevet har sin rod i antikken, men dukker på ny op i den centraleuropæiske barokdigtning. I Danmark får genren sit kunstneriske gennembrud hos Anders Bording med rimbladet til Gabel ( 1663) og Eres Knude etc. ... til Povel Tscherning ( 1664 ). Året før havde Peder Syv i sine Betenckninger over det Cimbriske Sprog præsenteret sin oversættelse af et $\gg$ Bindebrief $«$ af Opitz, og selv bidrog Syv med egne frembringelser til denne specielle art af rimbreve. Et kunstnerisk højdepunkt nåedes med Kingos bindebrev til Birgitte Balslev ( I 689). Bindebrevene forekommer i øvrigt i mere eller mindre raffinerede variationer helt op i sen-barokken med djærve poeter som Thøger Reenberg, Fakob Knudsen Skandrup og den af Grundtvig så højt værdsatte forgen Sorterup.

Det er både let og vanskeligt at forsøge på at give en holdbar definition af rimbrevgenren. Let, fordi man i og for sig kunne nøjes med at sige, at rimbrevet er et brev på rim, henvendt til en eller flere endnu levende personer, og derfor overholdende brevformularens indledende apostrofering af modtageren og en dertil svarende slutning - vanskeligt, fordi grænsen til anden form for lyrisk digtning (venne- og hyldestdigte) synes flydende. Et vigtigt kriterium synes det at være, at rimbrevet er ustrofisk og holdt $\mathrm{i}$ en parlerende associationsrig stil. Metrisk forekommer rimbrevet i barokkens tid enten i aleksandrinerens vægtige og rolige versemål, eller i Bordings lette firefods rytmer.

Særlige regler gælder for bindebreve, der som regel udstedes til 
adressatens fødsels- eller navnedag, og som foregiver at »binde« modtageren, hvorefter brevskriveren stiller betingelser for at »løse « ham eller hende. Ofte var bindebrevet et erotisk galanteri, til tider med nok så reelle hensigter. Ikke sjældent har bindebrevet karakter af supplique - bønskrifter til formående mænd, som man søger at »binde«, for at de kan »løse« sig ved at give rige gaver - eller eftertragtede embeder. Det gælder i øvrigt om baroktidens rimbreve som helhed, at de i vid udstrækning har karakter af bønskrifter. De formelig bugner af enevoldstidens umådeholdne smiger og flyder ud i hyklerisk ydmyghed.

I egenskab af epistel er rimbrevet intimt og privat i sit anlæg, en jeg-digtning, der giver digteren anledning til såvel fortrolige som åbne bekendelser. Det, der gør dem til kunst, er forfatterens vilje og evne til en artistisk udformning af sine bønner og betroelser, i første række med den hensigt at vække tilfredshed og bifald hos modtageren. Som genren udviklede sig, antog den mere og mere karakter af en subjektiv digtning, der tydeligt nok ikke blot var beregnet for adressatens øjne. De talrige afskrifter og de senere tryk viser, at man var klar over denne hensigt. Rimbrevet - hvad enten det havde karakter af supplique eller mere spøgefuldt binde-brev - blev af forskellige af senbarokkens digtere brugt som et påskud for en fri digtning, hvis indhold bevægede sig over mange forskellige temaer, hvorved samme rimbrev ved fri brug af associationer kunne manifestere sig inden for mange subgenrer som fabel, læredigt, nationale og fyrstelige hyldestkvad m. m. Ved I 7oo-tallets midte var genren på retur, men den dukker op igen mod århundredets slutning hos tidens store lyriske begavelser.

Helt overgiven er tonen i det dobbelt-rimbrev, som Ewald og hans ven Spendrup udformede i I $772^{1}$ ), præget som det er af et improvisatorisk lune, som synes at røbe generationsfællesskabet med fohan Herman Wessel, hvis følelsesladede rimbrev til den unge fens Baggesen på den anden side peger frem mod den fornyelse af rimbrevgenren, som det faldt $\mathrm{i}$ adressatens lod at afstedkomme. Ikke for intet bærer et af Baggesens fornemste værker fællestitlen: Skiemtsomme Riimbreve ( I 806). Titlen synes bevidst vildledende. Baggesens rimbreve er ikke lutter skæmt. De omfatter sandt nok erotiske, ja let fri-

I. Rimbrev til L. Bensen, Johs. Ewalds Samlede Skrifter IV, p. 386-389, VI p. 323-324 og 509. Jvf. tillæg til VI p. 4-6 samt Erik M. Christensen i Danske Studier, I 966, p. $59 \mathrm{ff}$. 
vole poesier - og digte, hvis indhold er det pure skæmt og galanteri. Men bogen rummer nogle af Baggesens vægtigste digtninge, først og fremmest rimbrevene til vennerne $A$. C. Gierlev og Walterstorf, breve, der har været sendt privat til adressaten, men som i let korrigeret (og forøget) form bragtes til trykken af forfatteren kun få år efter deres affattelse. Det er digte som Tilbagegangen over Rubicon, Paris og Rom, og Romerering - digte, der som senbarokkens rimbreve forener subjektiv betroelse med et spektrum af temaer, der associativt falder digteren i pennen, men som inspireret af musens lunerige sind bevæger sig fra lav- til højstil med en versifikatorisk lethed, der sprænger det bordingske firefodsvers' faste rytme.

Hos Baggesen forøges genrens spændvidde med det littercere rimbrev. Berømtest blandt disse poesier er rimbrevet Noureddin til Aladdin, der kaldte Oehlenschlager frem med sit kendte, lidt kantede bidrag til genren. Det blev ingenlunde Baggesens sidste rimbrev til den store romantiske skjald. Da han omkring de dramatiske begivenheder, som Napoleonskrigene kaldte ned over Danmark, søgte ny tilnærmelse til sin yngre digterfælle og dennes bedagede far, greb han atter til rimbrevet, ligesom han under indtrykket af fædrelandets ulykker gav sine følelser luft ikke blot i Knud Sjællandsfars sømandsviser, men også i rimbrevets form som f. eks. i det store rimbrev, som han betitlede Den danske Matros eller Flaskebrevet. Til Commandeur Jessen, Ridder af Dannebrog. ( I 808).

Allerede i barokkens rimbreve fandt poeterne mulighed for at udfolde sig satirisk. Hos Baggesen er det satiriske element latent til stede i de fleste af de »Skiemtsomme Riimbreve«. Efter hjemkomsten til København i I8I 2 og under de store litterære fejder med Oehlenschlægers unge forsvarere, udfoldede Baggesen sig med bidskhed og lune $\mathrm{i}$ en genre, der kunne betegnes som fejdebrevet - eller det litterært satirisk-polemiske rimbrev. Her dannede han skole. Hertz førte den litterære rimbrevsgenre videre i ren baggesensk stil (bl. a. i de anonymt udsendte Gjenganger-Breve ( I83o)), medens Aarestrup gik helt andre veje med sine såkaldte makamer, der blander prosa og henkastede rimerier $\mathrm{i}$ et intimt privatsnakkeri med adressaten. ${ }^{2}$ )

Hvor dybe spor Baggesens litterære rimbrevsfejder satte sig i dansk åndsliv, kan formentlig aflæses af den kendsgerning, at man med naturalismens gennembrud oplevede nye fejder i rimbrevets form - med

2. F. J. Billeskov Jansen: Danmarks Digtekunst III, I964, p. I6 $3 \mathrm{f}$. 
deltagelse af såvel ældre som yngre poeter, bl. a. Ploug og Kaalund, Schandorph og Drachmann. Og hermed var der ingenlunde sat punktum for rimbrevets forekomst inden for den danske digtning. Dets videre skæbne skal ikke følges her, hvor den ovenfor meddelte oversigt, der ingenlunde prætenderer at give en udtømmende fremstilling af rimbrevets historie i dansk digtning, blot skal tjene til en nødtørftig introduktion til de følgende bemærkninger vedrørende Grundtvigs bidrag til genren.

II.

Grundtvigs ældste, kendte rimbreve foreligger i et par manuskripter i fasc. $3^{87}$ i Grundtvig-arkivet. Ældst er et utrykt rimbrev til Broder Otto $i$ Torkildstrup (»Min velværdige Broder og Præst «), der med sikkerhed kan dateres til juli 1802 . Det er et ledsagedigt til et nu ukendt litterært satirisk produkt. Grundtvig kalder det »en tingest«, og satiren synes at have bevæget sig inden for slægtens og de nærmeste bekendtes kreds:

Over al Maade det skulde mig kildre

Hvis blandt de Objekter, jeg søger at skildre,

Du finder en Jafet, en Kam eller Sem,

Saa ej jeg behøver at sige Dig hvem -

Forbilledet for denne satiriske penneprøve, der bl. a. omtaler en fælles bekendt, der betegnes som:

... eders gelehrter Hof-Medicus Kok,

Hvis Kur ham har skaffet udødelig Ære

Blandt alle Kvaksalveres röhmlige (sic!) Flok,

kan være Baggesen eller andre af tidens satiriske versskribenter. Folk, der hovedsagelig kender digteren N. F. S. Grundtvigs senere versdigtning, vil formentlig have svært ved at udpege netop ham som disse linjers forfatter. Men stil og tone dukkede senere op i hans forsøg på at hævde sig i den litterære polemik inden for rimbrevgenren.

Et bevidst forsøg på at travestere genren foreligger $\mathrm{i}$ et rimbrev skrevet på Egeløkke i 1806: En underdanig Godmorgen til Den aerlige og gudelskende Kvinde Lorentze Hansdotter .. af Niels Frederik Søren fohansen, uvardig Praceptor, Skolemester og Ludimagister paa Egeløkke. Adressaten er pastorinde Graae i Bøstrup (der var født 
Birthe eller Bertha Lorenze Brandt). Dette rimbrev, der er studentikost og selvironisk i tonen, bærer mindre præg af samtidens (Baggesens) stil end af stilen hos barokkens rimbrev-skribenter. Brevet er trykt i Th. Graae: »Grundtvig paa Langeland« (I88o p. I5-17). Det hedder i brevet:

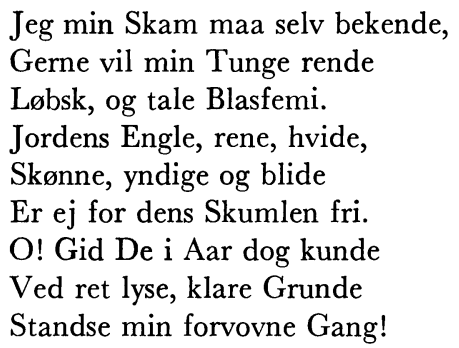

Først efter trængselstiden på Langeland og hjemkomsten til København ( I 8o8) træder Grundtvig frem som professionel versdigter, og først da kan vi forvente at møde rimbreve af æstetisk værdi inden for hans verdslige digtning. Hans rimbreve fra den æstetiske periode ( I808-10) er imidlertid uden dybere originalitet og har næsten kun kuriositetens interesse, småbidrag til hans biografi. Stilen er lånt fra Baggesen.

Det gælder f. eks. et par litterært-satiriske poesier i rimbrevets form: det i dag helt interesseløse rimbrev til en grundig glemt og helt underlødig skribent, Bod og Bedring, til Hr. Gundelach, Juni 1809 (P. S. I, p. 149). Skribentens dilettantiske betiser imødegås med grov grundtvigsk ironi, som er søgt forenet med tilløb til baggesensk elegance i rimbrug og ordvalg:

Du lasted og med Ret den Snak

Om Natten, der omhyller Kloden.

At der er lyst hos Antipoden,

Naar det er mørkt hos Gundelach,

Hvem tør vel nægte det! og dog,

Fordi den Frase var i Moden,

Mig Satan lettelig bedrog;

Han raabte til mig: Oehlenschlæger

Han var vel heller ikke Digter,

Den Gang han sagde, at Dagen dør,

Naar Natten udruller sit sorte Slør!

Jeg glemte, han var af den nyere Skole,

Jeg glemte vor Sol med de øvrige Sole, 
Jeg lo ad din Visdom og fandt,

Du var en Pedant.

Grovere i tonen er rimbrevet Til Hr. Professor Sander, som Digter, som Knud Lavards Forfatter og som Ven af Epigrammer (P.S. I p. I 23-1 30) offentliggjort 31. januar I8o9 - dagen efter førsteopførelsen af Sanders skuespil. Prologen til de sønderlemmende epigrammer om Sanders nyeste produkt har karakter af et rimbrev, der ligesom epigrammerne indeholder et voldsomt defensorat for Baggesen, overfor hvem Sander efter Grundtvigs overbevisning havde drevet et forargeligt dobbeltspil ${ }^{3}$ ). Rimbrevet, hvis snert også rammer Rahbek (ja strejfer Oehlenschlæger), frakender Sander enhver berettigelse til at føre digternavn:

Jeg maatte Alfabetet fuld

Med Alfabetets Navne skrive,

Hvis jeg en Liste skulde give

Paa alle dem, som ej vil stride

For Æren at staa ved din Side;

Men jeg vil skilles kort ved Tingen

Og rent ud sige: der er ingen,

Og kan ej heller nogen være,

Som bejler til den store Ære;

Thi, hvis mig ikke alting svigter,

Du netop er, hvad du vil være:

En tragisk, saare tragisk Digter.

Også dette digt har i dag kun historisk-biografisk værdi. Men det fortjener at kendes for nogle linjer, der djærvt og fyndigt udformer et sundt syn på kritikernes og litteraturhistorikernes holdning og opgaver:

Jeg holder mig ikkun til Bøger;

Thi naar jeg ogsaa stundum spøger,

Jeg holder mig til Mandens Bog

Og holder mig fra Bogens Mand,

Undtagen der, hvor Bog og Mand

Ej længere adskilles kan.

Fra omtrent samme tid som rimbrevet til Sander stammer fødselsdagsdigtet til alumnekammeraten på Walkendorfs kollegium, Hans

3. Se Grundtvigs prosastykke: Til Publikum (8. Februar I 8og) optrykt i P.S. I p. I 3 I og Albeck: Omkring Grundtvigs Digtsamlinger, 1955, p. 28. 
Hatting Laurberg: Domino Lauromontano die natali III. Apr. $M D C C C I X \ldots$ som Grundtvig ikke selv lod trykke, men som findes i P. S. I p. ı 06-ı o9, i sit indhold et sildefødt bidrag til bindebrevslitteraturen. Stilforbilledet er den skæmtsomme Baggesen. Digtet spiller tilstræbt muntert på de associationer, modtagerens navn: laurbærbjerget, kan give og vover sig lempeligt ind på det erotisk-frivole område. Brevets udgangspunkt er digterens bøn om et blad af laurbærlunden på Helikon, for at kunne imponere folk dermed. Han vil:

Fortælle Folk i høje Toner, Hvorledes Hr. Apollos Koner (Jeg egentlig hans Friller mener, Men Poesien alt forener) -

Hvordan hans Koner altsaa stjal

Den hele Krans fra min Rival

I Elskov og i Poesi,

(Apol jeg mener, som du ser)

Og listede sig alle ni

(Der er jo dog vel ikke fler?)

Til mig med Skatten

Midt om Natten.

Jeg denne Lejlighed tillige

Da greb, til halv om halv at sige,

At et Besøg ved Nat af Muser

Med mere end en Krans beruser.

En lignende kåd tone præger nogle strofer af et rim, der blev offentliggjort i Kirkehistoriske Samlinger (5. rk. 3. bind, p. 16-17)

Til

Hr. Inspektor Col. Walch. Hersleb

$\mathrm{Om}$

En ret Inspektors Kvaliteter

Og om

En slet Inspektors Udflugt

Kortelig

Paa Rim forfattet

af

Nicolao Frederico Severino Grundtvig

Collegii Walchendorphiani

Alumno

skrevet $\mathrm{I}$ 8. oktober $\mathrm{I} 808$. Rimet bryder med den klassiske rimbrevstil ved at være strofedelt og endog forsynet med et varieret omkvæd til 
hver strofe. Tonen er dog den intime brevstils og brevet en kollegianers hyldest til kollegiets inspektor på grund af hans evne til at overse de forseelser, han burde påtale. Også her bevæger Grundtvig sig ind på det frivole område, som f. eks. i strofe 3 :

Ifald for Eksempel Du kommer ved Nat,

Saa, hvordan det end udi Sengen er fat,

Om den er for fuld, eller ogsaa for tom,

Du alt dette Om

Ei ser som den blinde Inspektor.

Grundtvigs samtidige seriøse digte til venner på Walkendorf har ikke form af rimbreve. Han havde i sin anmeldelse af Baggesens »Skiemtsomme Riimbreve« (april ı 8og) kritiseret en række af de mere lunerige og intime digte, fordi de forekom ham alt for private til offentliggørelse (hermed stemmer, at han ikke selv befordrede de her omhandlede skæmtsomme breve til trykken), men samtidig med indlevelse og finhed fremhævet værdien af de mere tungtvejende bidrag til bogen: de to rimbreve til A. C. Gierlev: Rom og Paris og Romerering samt rimbrevet til Oehlenschlæger: Noureddin til Aladdin (af hvilket han lovede en mere indgående recension, som imidlertid aldrig fremkom ${ }^{4}$ ). Men paradoksalt nok skulle Grundtvigs vej til sine egne bidrag til en seriøs rimbrevdigtning til at begynde med gå uden om Baggesen.

\section{III.}

I I8I I fandt Grundtvig på ny anledning til at digte $\mathrm{i}$ rimbrevets form - $\mathrm{i}$ den overgangsperiode $\mathrm{i}$ hans verdslige forfatterskab, som fulgte på den akutte krise i i8ıо. Fra april-maj ı8ı I stammer en lille kreds af rimbreve af stærkt personligt bekendende karakter: rimbrevene til fonas Rein, til Sibbern og til Constance Leth, hvortil vist bør føjes digtet: Til Hans Gram Bechmann. I Anledning af hans »Drøm《 $i$ Sandsigeren $n r .40$ (trykt sst. nr. 48, 31. dec. I8I I), og fodselsdagsdigtet til Dannerkongen Frederik hin Sjette fra januar 1812, alle i samme jambiske metrum og stil. Af disse rimbreve lod Grundtvig selv de fire sidste trykke, hvorimod rimbrevet til Rein (uagtet Grundtvig havde stillet denne en offentliggørelse i udsigt)

4. Albeck: Anf. skr., i 955 p. 32. 
forblev utrykt og kun har kunnet rekonstrueres på grundlag af spredte kladdestumper i Grundtvig-arkivet (fasc. $\left.3^{86}\right)^{5}$ ). Adskilligt kunne tyde på, at Rein-digtet er det først skrevne af disse rimbreve. Denne antagelse støtter sig på den kendsgerning, at Grundtvigs stilistiske forbillede - ikke blot for brevet til Rein, men også de øvrige nævnte rimbreve - synes at være Reins Rimbrev til Sjallands hæederlige Biskop N.E. Balle (J. Rein: Nyeste Digte, I81 o p. I40-147)6). Reins rimbrev er affattet $\mathrm{i}$ parvis rimede femfodsjamber med regelmæssigt vekslende en- og tostavelsesrim og i en temmelig billedfattig stil. Indholdet er uden lyriske forsiringer, men myndigt forkyndende. En lignende holdning præger de her nævnte grundtvigske rimbreve fra I8 I I. Han tager sig i Rein-digtet visse metriske friheder, bl. a. ved $i$ et markant afsnit, som skildrer Grundtvigs krise i8Io-I I, at bryde rytmens faste taktslag og forkorte verslinjerne til 4,3 , ja i et enkelt tilfælde helt ned til 2 jamber. Det er formentligt rigtigt heri at se en imitation af Baggesens suveræne leg med rytmen vel at mærke ikke $\mathrm{i}$ spøgen og lunets tjeneste, men i et forsøg på rytmisk at illustrere den bevægelse, som bekendtskabet med Reins Nyeste Digte havde hensat ham $\mathrm{i}^{7}$ ). Ligeledes er det formentlig også påvirkning fra den baggesenske rimbrevspraksis, når Grundtvig hele digtet igennem lader afsnit med parvise rim veksle med passager med slyngede. Det samme forefindes i de her omhandlede rimbreve, hvis tone og tema alle er prægede af den religiøse krise 18 io og digterens dermed accentuerede trang til at meddele sine venner sine dybt alvorlige erfaringer. Til et sådant formål var stilen i Reins rimbrev til Balle bedre egnet end den lette, springende baggesenske tone. Den kom også til at præge andre af Grundtvigs rimbreve fra 18 i og det følgende år - f. eks. rimbrevet til Hans Gram Bechmann (P. S. I p. 428-435) og det gribende Farvel til Christian Molbech, i8ı 3 (P.S. III p. IOO $)^{8}$ ).

Måske vil det også være rimeligt at medtage det store digt Karen Bjørns Minde, som ganske vist er et mindedigt om en afdød, men som indledes med en apostrofering af »Danmarks Daatter« og sluttes

5. Albeck: Anf. Skr. I. p. 9I-IoI og 2I 5-219.

6. Albeck anf. skr. p. 89.

7. Albeck anf. skr. p. 97 .

8. I samme metrum og i en lignende stil som den omtalte gruppe digte er skrevet i, er det på tysk affattede digt An Stolberg, som Sv. Grundtvig formentlig med rette daterer til ${ }_{1} 8_{1} 2$ (PS. III p. 77-83). 
med et afsnit, der henvender sig til Grundtvigs daværende forlovede. Denne slutning er imidlertid en tilføjelse (se Grundtvigs egen forklaring i Tillægget til trykket i Kvædlinger (jvs. P. S. III p. I55)), hvorimod selve digtet $\mathrm{i}$ virkeligheden former sig som et rimbrev til Karen Bjørns sønnedatter, Karen Rothe, i anledning af hendes bryllup. Også dette digt er myndigt forkyndende, men holdt i en lettere metrisk form (trokæiske firefodsvers).

IV.

Først i I 8 I5, da Grundtvig foranlediget af Baggesens digt Drommen $i$ Kronprinsessegade nr. 390 Natten for den 28. Oktober, en dansk Fortalling af salig Baggesen (oktober $\mathrm{I}_{8} \mathrm{I}_{5}$ ) og især efter at Baggesen havde offentliggjort Det evige Sindbillede (nov. 18I5) lagde Grundtvig op til en polemik i rimbrevets form, men under titlen af Rimelige Strøe-Tanker ved Kalundborgs $i$ Livet vel meriterede Stads-Satyrikus fens Baggesens Grav. Strøtankerne, der blev offentliggjort i 5 numre af Nyeste Skilderie af Kjobenhavn I8 5 i tiden I I.-25. november, er formelt eet stort rimbrev i baggesensk stil og blev optakten til den såkaldte Valhallaleg.

Adressaten er dog ikke Baggesen, men hans små modstandere, som Grundtvig tager alvorligt i skole, samtidig med at han får luft for sin kritik af Baggesen. Et forsøg på at bryde ensidigheden i forholdet mellem Baggesen og hans kritikere, men også et forsøg på at stege Baggesen i hans eget fedt. Stilen efterligner adskillige steder ikke uden held Baggesens rimbrevstil og stilen fra Gengangeren og han selv.

Til trods for, at Baggesen følte sig ramt navnlig af det fjerde afsnit, altså midt under offentliggørelsen af det samlede rimbrev, tilstod han offentligt i en note til sit Parentetisk Interims-Svar til den mig ubekjendte Forfatter ... etc., at Grundtvigs Strotanker efter hans opfattelse »fra Vittighedens Side betragtet, ikke blot er ulignelig mere værdt end alt tilsammen taget, hvad man hidindtil har trykt og undertrykt imod mig, men et klassisk Mesterstykke i den burleske, ægte danske Satire ... . $\left.\ll^{9}\right)$.

Men da de var kommet på skudhold af hinanden efter Grundtvigs offentliggørelse af et rimbrev til Baggesen benævnt Gaade-Gixetnin-

9. P. S. IV p. 148 . 
$\left.g e n^{10}\right)$, og navnlig efter den såkaldte efterskrift med titlen Rimelige Stroe-Tanker sammengroede $i$ Gaade-Giatningen til Jens Baggesen (28. nov. $\left.\left.18 \mathrm{I}_{5}\right)^{11}\right)$, fik tonen en anden lyd. I sit vægtige, hovmodige og groft kritiske rimbrev til Grundtvig offentliggjort 5. dec. I8 15 under titlen Tankesamleren $i$ Hiertet er anerkendelsen behæftet med voldsomme forbehold og ordvalget pyntet op med grove invictiver, Strøtanker karakteriseres som »dit satirisk-genialske Vrøvl《 eller »dette lange genialske Hjask «.

I dag vil man nok være tilbøjelig til at slutte sig til Baggesens seneste karakteristik fremfor den første. Skønt Grundtvig rullede sig voldsomt ud i Strotanker, var det klart nok, at han optrådte i et lånt kostume, når han søgte at efterligne Baggesens rimbrevstil, og at netop denne genre frembød farlige fristelser for ham til at give sig sine løbske verbale associationer $i$ vold.

Men alligevel affødte Valhallalegen nogle vægtige rimbreve fra Grundtvigs hånd. Det gælder i mindre grad digtet Gaadegicetningen, hvor stilen fra Baggesen endnu er mærkbar, men hvor Grundtvigs egen røst lader sig høre i linjer som disse, der i fuld oprigtighed søger at give Grundtvigs beundring og hengivenhed for digteren Baggesen poetisk udtryk:

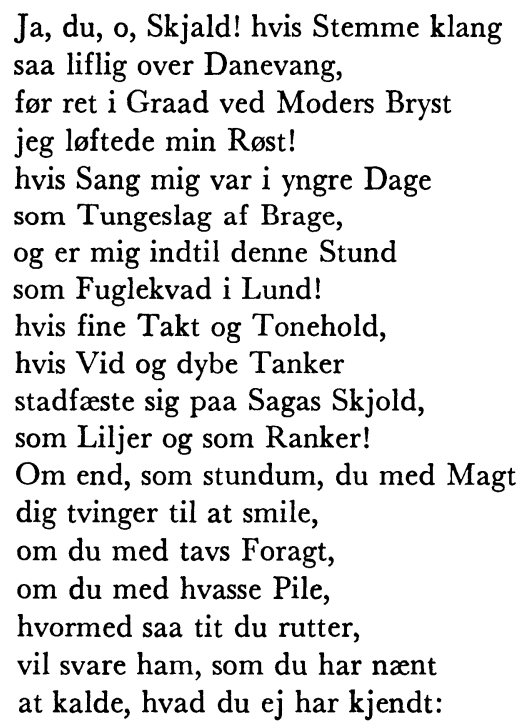

Io. P. S. IV p. 197-200.

II. P. S. IV p. 2 II. 


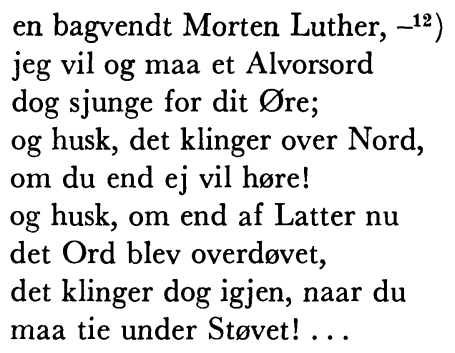

En mere personlig tone præger Efterskriften til Gaadegicetningen, hvis vægtigste partier er formet i femfods-metret fra 18 i I-brevene og holdt $\mathrm{i}$ en beslægtet verbal stil. Helt grundtvigsk er tonen i digtet Til Sfinx, hvori han svarer på Baggesens på en gang ømme og nedladende digt Til Heimdall. Det bryder helt med rimbrevsformen, for så vidt som det er regelmæssigt strofedelt. Man kunne fristes til at betegne dette og lignende strofedelte digte, hvis indhold ligger brevformen nær, som brevdigte. Karakteren af brevdigt fremgår af slutstrofen, der former sig som et postscriptum til et brev:

Dog, Hjærteordet lader sig ej tvinge.

Gid, Baggesen! du mesterlig fuldbringe,

Hvad jeg har kjækt og ærlig fusket paa!

$\mathrm{Da}$ véd jeg vist, at under Lysets Vinge

Min Broderhaand, mit Venneraad saa ringe

Du nænner ej at haane og forsmaa.

Strofen, ja hele digtet, gjorde indtryk på Baggesen netop i kraft af den dybt personlige stil. I en prosaredegørelse af 20-.21. jan. I 8 I 6 taler han om »Gjallarhornets dybe Hjærteklang i Tusmørkekvadet Til Sfinx med den sidste, dybt i mit Hjærte gjenklingende Tone ...«. Denne positive holdning hos Baggesen udløste den helt store forsoningsreaktion fra Grundtvigs side $\mathrm{i}$ form af brevdigtet: Til fens Baggesen. (Aabent Fejdebrev) (Marts 1816). Brevets apostrofering er som et orgelbrus for fuldt register:

12. I en artikel i sit blad Lille Søndag Aften (nr. ro, p. 40 og optrykt i OranUtang ved Foden af Parnas (1814)) havde Baggesen betegnet Grundtvig som en »bagvendt Morten Luther «. I et ikke trykt svar (Grundtvig-arkivet, fasc. I 79, nr. I) skriver Grundtvig: »... i dette Stykke kan jeg ikke tro Deres Øine, da De udentvivl aldrig har seet Morten Luther lige i Ansigtet, thi i saa Fald saa De vist hellere hans $\mathrm{Hæl}$ end hans Taa... og det er vist, at naar galt skulde være vilde jeg tigange hellere være en bagvendt Luther end en Baggesen op ad Dage - «. 
Velkommen du, hvem jeg har ventet længe!

Velkommen du, hvis Døvhed bandt min Mund!

Velkommen, Aand, i gamle Danmarks Vænge!

Velkommen, Aand, i Skjolds Kjærmindelund!

Velkommen, Aand, som ynkes over Vrimlen!

Velkommen, Aand, som stirrer op mod Himlen

Og spejder Stjærnerne paa Nattevagt!

Brevdigtet toner ud i forvisningen om, at de to i fremtiden vil stå sammen i kampen mod åndløsheden:

Lad nu imellem os et Ord det være,

At vi vil hjælpes ad med ærligt Sind,

Og se, om vi ej Drengene kan lære

At stikke Halerne og Piben ind,

Saa uden Ros og uden Last af Drenge

Vi kæmpe kan i Danmarks gamle Vænge,

Og ægte Dannemænd faa Ørenlyd!

Ja, skulde én af os, imens vi stride, Bagsmækkes af en Nidding eller Pog, Da lad udtrykkelig ham forud vide, At to han træffer under Danebrog, $\mathrm{Ja}$, indeklemmes ganske mutters ene Imellem tvende, ja, to haarde Stene,

Der male, knuse ham saa smaat som Smul!

Også her har Grundtvig skrevet et regelmæssigt strofedelt »brev《 vidt forskelligt fra tonen i Baggesens rimbreve, men både rytmisk og stilmæssigt i slægt med rimbrevene fra i 8 i I !

Professor Aage Henriksen, der har foretaget en dybtgående og åndfuld analyse af forholdet mellem Grundtvig og Baggesen, og som ikke mindst ofrer Valhallalegen megen opmærksomhed ${ }^{13}$ ), peger med rette på, at Grundtvig hastigt efter fejdebrevets uforbeholdne venskabserklæring blev grebet af ny »uro ved Baggesens ekstreme, lovløst udskejende væsen«, og at denne uro »gav sig til kende i et digt, der er langt og svært, plaget og mørkt, i tonen fjernt fra det klare velkomstdigt og fra det dristigt grove opgør med den gudsforgåene grinebider $\left.\ll^{14}\right)$.

Digtet, der virker ufuldendt og fragmentagtigt, er offentliggjort i Danne-Virke, juli I8I6, bærer titlen Afbrudte Strøtanker ved Brevet

1 3. Kritik, I, I 967, p. 89-1 I 2.

I4. anf. afh. p. Iog. 
til Vali Magni og er et svar på et digt af Baggesen Til Vali (skrevet i november I8I5, men først offentliggjort 2. marts 1816). Grundtvigs digt har ikke karakter af rimbrev (eller brevdigt) - og blev heller ikke benyttet som led i en ny strid. Når Grundtvig optog det i DanneVirke var det, fordi han syntes, at fragmenterne havde »noget, af Striden uafhængigt, poetisk Værd« -. Han taler i et tillæg til trykket i Danne-Virke om versenes »Livlighed og Velklang ... thi disse Egenskaber gjør ikke blot, at man med en Slags Fornøjelse kan læse selv det dunkleste, men er, efter min Forstand, ogsaa et sikkert Pant paa, at der svævede noget dejligt for Skjalden, skjønt han hverken var i Stand til at klare det for sig eller for Læseren $\left.\ll^{15}\right)$. - I virkeligheden var Grundtvig, der gennem Baggesen var blevet trukket ind $i$ et nyt spændingsforhold mellem nordisk mytologi og gådefuld poesi, på vej ind $\mathrm{i}$ en ny digterisk udtryksform, der nåede sit højdepunkt med Nyaars-Morgen 1824 .

\section{V.}

Udover rimbrevebidragene til fejden med Baggesen har Grundtvig formet nogle rimbreve til Ingemann. I i 8 I 7, altså året efter Valhallalegens ophør, offentliggør han en lille afhandling i Danne-Virke II p. 97-Ioo med titlen Rimbreve og lovede, at han under »dette uskyldige Navn ... af og til, efter Stemning og Omstændigheder « ville sige sine »uforgribelige Tanker om adskilligt i Bogverdenen, mest Smaating og Uting, ingenlunde for at gjøre stort Væsen af ingen Ting eller Fluer til Elefanter ...«. Han har som i Rimelige Strøtanker et godt øje til »adskillige haabefulde Ynglingers Mening«, men nu er det mere Ingemanns og hans egne angribere, han vil til livs, end Baggesens. Han overlod gerne andre, »som dertil havde mere Anlæg, Tid og Færdighed, den Bestilling «, men finder ikke sin egen aktivitet overflødig, eftersom han ikke er ganske tilfreds med den polemik, Baggesen fører mod de samme frække ignoranter: »Vel tørrer den halvopstandne Stads-Satyriker fra Kallundborg imellem Stunder baade smaa og store ganske artig; men dog sjældent ret efter mit Hoved, og end sjældnere - hvad her er Hovedsagen - efter mit Hjærte «. Grundtvig vil derfor, indtil Baggesen selv, »eller hans lovlige Eftermand, kan faa i Sinde at røgte sit Embede ordentlig, fungere som

15. Danne-Virke, 1816, I. Her citeret efter P. S. IV, p. 256. 
konstitueret ...«. Ja, Grundtvig forbeholder sig ret til også at svinge svøben over Baggesen, »om jeg finder det fornødent«. Han synes i det hele taget at have været veloplagt til påbegyndelse af en ny litterær rimbrev-polemik. Afhandlingen står som en indledning til, hvad Grundtvig kalder Forste Rimbrev, som er rettet til B. S. Ingemann. Brevet selv er holdt i baggesensk stil og indeholder samme lyder og dyder som versene i Rimelige Strotanker, men altså her et defensorat for Ingemann forenet med et angreb mod »Athenes« spottende drenge $\left.{ }^{16}\right)$.

Men grovest er han i kritikken af fohan Ludvig Heiberg, der i fulespog og Nytaarsløjer ( 18I 7) uskånsomt havde hudflettet Ingemann og ikke mindre Blanca's sentimentale publikum. I sin polemik mod Heiberg er det som han søger at overgå den Baggesen, der et par år tidligere havde ladet invektiverne hagle over Grundtvig i rimbrevet Tankesamleren i Hjertet til Strøetonkeren i Munden (Kjøbenhavns Skilderie, 5. dec. I8I5), og hvori Baggesen - som han stundom yndede - legede frækt med bibelske og kristne forestillinger:

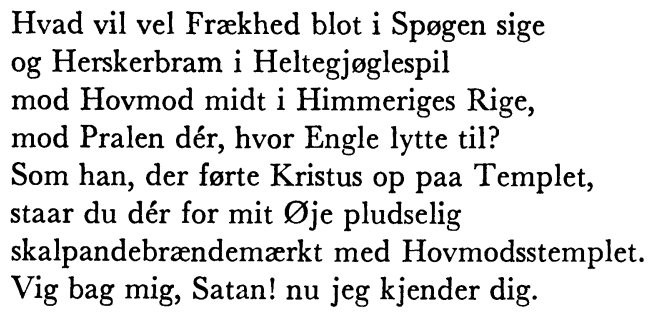

Slet så direkte går Grundtvig ikke til værks i sit angreb på Heiberg. Den unge digterspire præsenteres på et tidligt tidspunkt $\mathrm{i}$ rimbrevet som »den Dukkemand i Aabenraa«, og da turen kommer til bandstrålen mod fulespøg og Nytaarsløjer, er det både dette satiriske værk og dets digter, som betegnes som »det søde Julenor $\ll$ og »din lille Dukkegud«. Medens Grundtvig i Baggesens satiriske billedsprog identificeres med Satan, bliver »Noret《 og den »lille Dukkegud « eet med Jesusbarnet:

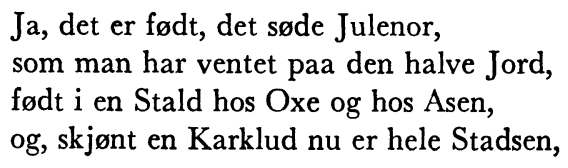

16. P. S. III, p. 371-383. 
som baade tjene maa til Svøb og Ble, man dog i ham maa Rigets Arving se; det er forkyndt for Hyrder og Hyrdinder, som man paa Markens Skueplads dem finder, og Østens vise med det første komme, med Kongerøgelse i hver en Lomme, med Pebernødder og med Guldpapir, til Julegave og til Nyaarssir.

Kom, sig, du vantro! nu, at Verden løj! se Julebukken ved det gamle $\varnothing_{\mathrm{g}}$ forstum! nedknæl! bekjend, at det er stort! Oplysningen er nu fuldkommen gjort! Hvad var det, Verden! vel du pønsed paa? mon ej en Søn, som kunde bag op slaa, ja, slaa Spar To til Djævel og til Engel og midt i Helligdommen spille Pind; kort sagt: en fri, selvstændig, lystig Bengel, sin egen Gud, sin egen Harlekin!

$\mathrm{Nu}$ har du ham, Triumf! Triumf! til Lykke!

Som hans udødeligt er nu dit Navn, du Liljevand! du Jomfru Kjøbenhavn! din Gudsøn flux med Faldehat du smykke! Dog nej! paa fire trygt gaar Julebukken, og Kæmpeværk din Søn gjør alt i Vuggen; men vogt dig selv og ham for Spot og Skade, og snør ham flux i Panser og i Plade, at ej maaske Herodes' Sendebud skal slaa ihjel din lille Dukkegud!

Det er unægtelig en noget anden poetisk anvendelse af Juleevangeliet, end den Grundtvig syv år tidligere havde givet i Deilig er den Himmel blaa. Der skal nok være dem i samtiden, der har undret sig over, at Bibelens ensomme kæmpe ville lægge navn til en slig gang »blasfemi«. Grundtvig var nu en gang tilhænger af det gamle ord om, at »Som man raaber i Skoven, faar man Svar«, og Heiberg havde i sit elegante satiriske værk ikke nægtet sig noget. Men hvad der måske var nok så væsentligt - Grundtvig kendte af bitter erfaring slagkraften i denne polemiske form. Noget andet var, at han savnede Baggesens mesterskab i det underfundigt og smidigt satiriske og derfor blev et let offer for Heibergs bidske modkritik ${ }^{17}$ ).

17. Da Grundtvig i oktober-november 1818 gik i krig med Tylvten og bebrejdede de unge skribenter deres ubarmhjertige adfærd over for en så fortjenstfuld ældre digter som Baggesen, ransagede han sin samvittighed. Havde han ikke 
Et andet rimbrev til Ingemann fik Grundtvig ikke skrevet færdigt. Det kendes kun fra udkast til hans digt Kjorminde-Bladet, til Bernhard Severin Ingemann, 1818, skrevet i anledning af Ingemanns store udenlandsrejse. Rimbrevet sætter i med meditationer over begrebet farvel og farvelsituationer med ord og vendinger, der går igen eller udvikles nærmere $\mathrm{i}$ det store strofiske »brevdigt« Kjorminde-Bla$\left.d e t^{18}\right)$. Efter en mere alvorlig optakt, slår Grundtvig i rimbrevs-kladden mere og mere på de skæmtsomme strenge og nærmer sig Baggesen-stilen:

Kun skjæmte vil jeg med de lange Rejser

Og med hvad udenlands man ser og hører,

Dog egentlig kun med de lange Ører

Og alt, hvad Rejser gjøre skal til Kejser,

Jeg skjæmter højt, fordi det var paa Tiden,

Man lærte: ej at rejse efter Næsen;

Jeg skjæmter drøjt, for man skal føle Sviden

Og ikke slippe med et fornemt Væsen.

Til dig jeg skriver, da $d u$ netop rejser,

Da vi hinanden da omtrent forstaa,

Da du i Kikkerten har ingen Kejser,

Og lader allenfals min Knebber gaa.

Følgende fire linjer, der findes på samme kladde, kunne tyde på, at Grundtvig ville begynde helt forfra med sit rimbrev i en endnu mere overgiven stil. Herpå tyder apostroferingen af Ingemann:

I, se god Dag, min Bror! hvor gjælder Rejsen?

At sige: ikke den i Dag, men den i Morgen,

Den Pokkeren i Vold, der ud til Svejsen,

Til Myklegaard, til Hurliburli-Borgen.

Rejsemotivet var et altfor alvorligt motiv for Grundtvig. Han kunne ikke gøre sit rimbrev færdigt. I stedet skabte han det store Kjarminde-Kvad, som i femfods-strofer formaner Ingemann til at huske, hvad fædrelandet kræver af sine sønner, og advarer den bort-

selv i sine yngre dage gjort sig skyldig i lignende »udanske« forseelser? I et utrykt udkast (fasc. I 8o, nr. I 2) angrer han angrebene på Rahbek og Sander! (jvf. ovf. p. I2) og i samme udkast misbilliger han, at han i rimbrevet til Ingemann »om Drenge-Væsenet i Litteraturen « har anbragt »eet Træk, som kunne saare en dansk Følelse hos den unge Heiberg «. Han finder dog nogen »Undskyldning for den jeg vil haabe i Heibergs Øine ellers utilgivelige Fornærmelse, der blev mig tilføiet« (af Heiberg).

I8. trykt i Danne-Virke IV, I8 19, p. I55-I 72; P. S. V, p. 9-22. 
dragende imod at lade sig friste af Sydens tillokkelser og udanske væsen. Digtet mister med hele sin stærkt retoriske opbygning og med sine mange tungt skridende strofer med reflektorisk indhold næsten helt karakteren af brev. Ikke desto mindre aner man i en enkelt strofe en reminiscens af den gamle bindebrevsgenre:

$$
\begin{aligned}
& \text { O! er det saa: Kan hist i fjærne Egne } \\
& \text { Det lille Blad fra Bøgelund udsendt } \\
& \text { Vor Moders Øjne venligt dig betegne } \\
& \text { Med Taareperlen klar og himmelvendt, } \\
& \text { Da skal det Blad end fastere dig binde } \\
& \text { Til Bøgelunden og til Dans Kjærminde. }
\end{aligned}
$$

Efter i stærkt manende ord at have advaret Ingemann mod at lade sig blænde af Romas kødelige kunst og Sydens jordiske pragt, søger han at lede sin digterfælle, Blancas digter, ind på et område, hvor de to digtere kunne øve fælles dåd: den national-historiske digtning:

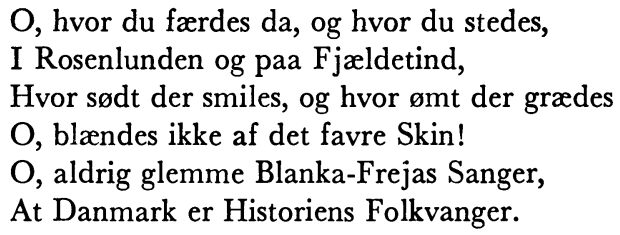

Ingemann fulgte opfordringen - efter hjemkomsten fra den for ham så betydningsfulde Romafærd - med udsendelsen af Waldemar den Store og hans Mand (1824). Værkets betydning for Grundtvig er velkendt. Så meget stærkere virker det her i dette brevdigt at se, hvorledes Grundtvig allerede i I 818 fabler om, hvordan et fællesvirke mellem de to - $\mathrm{i}$ grunden så forskellige - digtere kunne genoplive Danmarks ånd - i Kicerminde-Bladet personificeret som »vor Moder $\ll$ :

Da skulde levende vor Moders Minde

Opkomme og opstaa i alles Bryst.

Med Frejas Rosengjord os sammenbinde

I én til ét: til fælles Værk og Trøst;

Da midt iblandt os skulde, ved et Under, Oprejses hun, som dødningbleg nu blunder.

Ingemanns episke digt om Valdemar den Store gav i øvrigt anledning til 2-3 rimbreve (eller brevdigte) fra Grundtvig. Det ene skal blot nævnes, for så vidt det ikke ganske dækker »genren«, som her 
er søgt indkredset. Det er det i For Idé og Virkelighed i 1869 offentliggjorte dedikationsdigt i Ingemanns eksemplar af Grundtvigs Saxo-oversættelse fra $\left.1823^{19}\right)$ : Her kommer Thorkild Dane. De to andre er et af Grundtvig selv som rimbrev betegnet brevdigt som tak for tilsendelsen af Waldemar den Store og hans Mand (1824), og hans Trostebrev i Sorgen over Kong Valdemar og hans Mand (Nyeste Skilderie af Kjøbenhavn i6/ I I 1824$)^{20}$ ).

Takkebrevet er blevet til i sommeren 1824 , medens Grundtvig arbejdede på Nyaars-Morgen. Dette forklarer, at brevet er skrevet i samme strofeform som det store digt og oprindelig indledt med ordene: »Kjære broderlige Ven! Guds Fred! hvor I bygge« efterfulgt af 6 linier fra en strofe i et bevaret udkast til Nyaars-Morgen. Ved sin stil og strofiske opbygning må det genre-betegnes som brevdigt. Brevets indhold er dels en følt tak for værket - og en poetisk irettesættelse af Ingemann for det - lidt uærbødige og let komiske - billede han i sit episke digt havde tegnet af Saxo.

Med Trøstebrevet vendte Grundtvig tilbage til det litterære rimbrev: fejdebrevet, og til den skarpt ironiske tone. Brevet fremkom, ret usædvanligt for Grundtvig, under pseudonym: Giengangeren. Ifølge Svend Grundtvigs oplysninger »synes Samtiden ikke at have genkjendt Forfatteren $\ll^{21}$ ), hvorimod Ingemann ikke var i tvivl om, at brevskriveren var Grundtvig. Om det nogensinde kom den ekspatrierede Baggesen for øre, at hans gamle modstander og kampfælle havde ranet hans berømte pseudonym - måske i den bevidste hensigt at konfundere den københavnske læseverden - vides ikke. Tjent med at blive forvekslet med Grundtvig som rimbrevdigter kunne han ikke være, skønt digtet ikke er ubetinget kompromitterende for sin ophavsmand.

Til underfundigheden i digtet hører, at Grundtvig nævner sig selv ved navn i digtet og tilsyneladende også satiriserer over sig selv:

At Grundtvig vilde, om han kunde,

Nedrive Kunstens Hovedstad,

Saa alle Former gik til grunde,

I et kaotisk Sagakvad. -

19. jvf. Grundtvig og Ingemann etc. p. XXXIX-XL. Grundtvigs øvrige dedikationsdigte har ikke i samme grad affinitet til rimbrevgenren.

20. P.S. V p. 295-318 og U.S. IV p. 345-364 (med kommentarer. Jvf. Rønning III, 1, p. $67-68$.)

21. Grundtvig og Ingemann etc. p. XLIX. 
At Dansk for ham var det paa Trods

Som Tysk med rette er for os:

Det ret naturlige, normale,

I Tungemaal, i Sang og Tale,

Saa hans den grove Aristark

Hed gammel Skik i Dannemark. -

Det vidste man, det lo man ad,

Da længer ei man fnyse gad -

Men Ingemann!

- - -

Hvem skulde tænkt, at Ingemann

Hjemkommet nys fra Kunstens Land,

At Sangeren ved Skjønheds Alter,

Naar han fornam den Sag var ren:

Der maatte sættes Kjød og Ben

Til Blankas luftige Gestalter, -

At han med samt sin Poesie,

Som dog naturlig var at kalde,

Da skulde sørgelig forfalde

Til et historisk Kætteri

Og bygge paa et Dannevirke,

Som, synker det ej brat i Jord,

Adskille maa det hele Nord

Fra Kunstens tysk-katolske Kirke. -

Rimbrevet er gennemført satirisk, men uden hverken elegant eller slående kraft $\mathrm{i}$ ironien, et sjap-digt uden koncentration og derfor trods gode enkeltheder svagt i sin virkning. Det rummer enkelte tilløb til metrisk raffinement $\mathrm{i}$ baggesensk stil, men som helhed må man sige, at Grundtvigs forsøg på at optræde som Baggesens genganger var mindre lykkeligt ${ }^{22}$ ). Ingen kan have været $\mathrm{i}$ tvivl om, at hverken hånden eller ånden var Baggesens. Da Henrik Hertz 5-6 år senere påtog sig rollen som genganger (Gjenganger-Breve, I $83^{\circ}$ ), var det med en anden og forbløffende virkning.

Der findes flere og senere eksempler på rimbreve i den parlerende wessel-baggesenske stil fra Grundtvigs hånd, men det er i hovedsagen private breve, som først eftertiden har ladet trykke. Et af de seneste er Grundtvigs Rimbrev til Lise, hans første hustru, med datering I 2. august I835. I brevet, som er offentliggjort af Jørgen Fabricius

22. Om Grundtvigs tilskyndelse til at føre krigen mod Ingemanns kritikere »med lette Tropper《 - se Grundtvig-Ingemann etc. p. 38-39. Om Trøstebrevet i øvrigt ibid., p. 32 f. 
(Grundtvig-Studier, I955, p. 82-85), findes et par linjer, hvori Grundtvig tilstår sin afmagt over for den milde og yndefulde kunst:

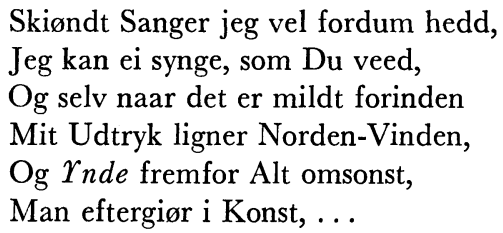

Selv om linjerne har et andet og mere intimt bekendende sigte, virker de som en sen erkendelse af, at Grundtvig måtte komme til kort, når han søgte at konkurrere med Baggesen. Derimod havde han held til at finde sin egen rimbrevstil, når han søgte tilbage til tonen fra de stærkt personlige rimbreve fra $\mathrm{I} 8 \mathrm{I}$ I, hvad enten han gav sine epistler rimbrevets eller brevdigtets form.

\section{VI.}

Blandt rimbrevene fra $181 \mathrm{I}-13$ indtager digtet Til Dannerkongen Frederik hin Sjette paa Hans Fødselsdag den 28 de Fanuarii ${ }_{1} 8{ }_{1} 2$ en særstilling. Det peger frem mod hans vægtigste og mest selvstændige anvendelser af rimbrevsgenren. Det er affattet i samme metrum og stiltone som de øvrige rimbreve fra samme tid (ovf. p. 14) og indledes med en ydmyg tiltale til kongen:

Vil paa Din Dag, o, Frederik! du tilstæde

En Landsbyskjald i Kongesal at træde?

en anråbelse, der, som jeg tidligere har påvist ${ }^{23}$ ), er kalkeret over Forgen Sorterups store dedikationsdigt i Nye Heltesange ( I 7 i6), men som bevidst søger at undgå barokdigtningens svulst og smiger. Digtet er en tak til kongen for forordningen om oprettelsen af et norsk universitet og afspores som rimbrev til kongen i det store midterparti, der apostroferer Norge og nordmændene i en grad, så digteren helt synes at glemme den kongelige adressat. Men mod slutningen griber han sig i sin eskapade (som i øvrigt er et fænomen, der er typisk for barokkens store rimbreve), og henvender sig på ny til kongen i forvisning om, at kongen vil tilgive ham digressionen:

23. Albeck: anf. skr., p. I I 5 . 
Ej, milde Konge! du fortørnes vil,

Fordi, imedens du var selv til Stede,

Jeg glemte, som det lod, til dig at kvæde,

Og talte længe ikkun Norrig til.

Herefter får brevet en lignende karakter som de andre af hans samtidige rimbreve - en indtrængende forkyndelse af det kærlighedens evangelium, der var frugten af hans hovmods fald, vedføjet stærke advarsler mod følgerne af rationalismens vækst og den sande, enfoldige gudstros forsvinden samt en bøn til Herren om, at

\author{
... styrke ham (kongen), ihvor han gaar og staar, \\ Til godt at ville og til godt at virke, \\ Til kraftig at beskjærme Kristi Kirke, \\ Saa ingen, der for Tidens Afgud knæle, \\ Sig skal indsnige til at myrde Sjæle, \\ Men at i Nord den maa urokket stande, \\ Naar den nedbrydes rundt om Lande! \\ Gud tage naadig i sin Varetægt \\ Din fromme Dronning og din ganske Slægt! \\ Han dig stadfæste udi Kjærlighed! \\ I Liv og Død han skjænke dig sin Fred!
}

Hidtil havde Grundtvig i sine rimbreve henvendt sig med sit budskab til den enkelte ven. Nu søgte han gennem den enkelte, kongen - i rimbrevets form - at få tvillingerigets indbyggere i tale. Der går en linje fra dette rimbrev - over digtet Freden, i813, (P. S. III p. I 24-39) med den kraftige apostrofering af »Fæderneland « og »Broder og Søster paa Fjæld og Vang «, over digtet Faderneaaret, Velkomst i Vaar til Dannerkongen, I8I 5 - til Nyaars-Morgen, hvis særprægede strofeform allerede er foregrebet og benyttet i Faderneaaret. Det er i denne forbindelse værd at huske, at Grundtvig - ved fremkomsten af sit store bekendende og forkyndende digt - som han på titelbladet havde karakteriseret med undertitlen »Et Rim ...«, i et par samtidige breve betegnede Nyaars-Morgen som et $\gg$ Rimbrev《. Således indleder han sit brev af 3. sept. 1824 til Ingemann, hvor han sender Nyaars-Morgen til sin soranske ven, med følgende passus:

»Ret hjærtelig Tak for Dit Brev, som vel især er for så vidt blevet ubesvaret, fordi hvad jeg følte Trang til at sige mine Venner, og dig iblandt dem, sammentrængte sig i det Rimbrev, som hermed følger $\left.{ }^{24}\right)$.

24. Grundtvig og Ingemann, Brevveksling $1821-1859$, udg. og indledet af Svend Grundtvig, Kjøbenhavn I 882, p. 23. 
Og $\mathrm{i}$ et brevfragment fra samme tid (med ukendt adressat) hedder det (om Nyaars-Morgen):

»Imidlertid, det er et Rim-Brev til mine Venner og til hvem der vil være det, udstrømmet saaledes af Hjertets Fylde, som Intet af min forrige Skrift, det har været mig en Højtid at føle (og) skrive det, og saa Gud i Vold! $\aleph^{25}$ )

Ved sin faste strofeopbygning og sin dunkle profetiske tale skiller det sig både formelt og indholdsmæssigt fra det klassiske rimbrev men den direkte påkaldelse af adressaten er bevaret såvel i digtets optakt som slutning:

Guds Fred, hvor I bygge,

i Mark og paa Fjæld -

Man kan sige, at Grundtvig i Nyaars-Morgen sprængte rimbrevsformen. Man kan også tale om en vældig udspænding og udvidelse af genren. Afstanden til det baggesenske rimbrev er blevet uendelig stor, karakteren af seriøs digtning eneherskende.

Kun en enkelt gang endnu brugte han selv betegnelsen rimbrev på en af sine til offentliggørelse bestemte digtninge, nemlig Rimbrev til Nordiske Paarorende (indledningsdigtet til Nordens Mythologi, I832). Adressaten er her den samme som i Freden og Nyaars-Morgen: Folket i Nord - vel at mærke ændret fra det dansk-norske folk til alle nordiske pårorende, eller med hans egen nye formulering:

Sønner og Døttre af Nordens Aand: -

Formelt nærmer Grundtvig sig her en mere klassisk rimbrevform. Versemålet er ikke det tungtskridende jambiske - fra I8 I I-I 3 årene - men en djærv daktylisk rytme uden strofedeling, og indholdet, hvis forkyndelse ikke er mindre seriøs end de ældre rimbreves - bæres af en tone, der er rask, æggende og blandet med underfundigt lune. I dette digt går arven fra Baggesen og reminiscenser af den tunge, vægtige forkyndelse fra kriseårene op $\mathrm{i}$ en højere frigjort enhed.

Hans sidste store rimbrev Aabent Brev til mine Børn, $1839^{26}$ ) er i sin metriske form på linje med de fortrolige rimbreve fra 18 I I-I3. Oprindelig er brevet blot rettet til hans to sønner og formet i et firefods trokaisk vers:

25. Grundtvig-arkivet fasc. 509,2.

26. P. S. VI, p. $24^{2}$ ff., udkastet trykt i P. S. VI, 247-257 under titlen Til mine to Sonner. 
Sønner mine, lige kjære, Begge af det ene Kuld, Moders Haab og Faders Ære, Som de findes kan i Muld! Lytter til min Alvors-Tale Ikke blot den Dag i Dag, Men naar jeg er lagt i Dvale Under Græstørv-Hyttens Tag.

Dette digt er didaktisk og faderligt formanende og kunne i sin opbygning minde om tilsvarende rimbreve fra barokkens tid f. eks. Sorterups Dydens Enge og Lastens brede Vej. Da Grundtvig udformer det åbne brev til sine børn og vælger at give det den ham mest fortrolige rimbrevsform, hæver brevet sig op i en højere poetisk sfære. Det var af dette digt han som gammel kunne udtage et afsnit, der med en enkelt tilføjelse blev til en af hans mest værdsatte verdslige sange: Et jaevnt og muntert, virksomt Liv paa ford. Der skete med andre ord det paradoxale, at han via et rimbrev, der havde så privat og intim en adresse, som kun et brev fra en fader til hans børn kan have, fik hele det danske folk i tale.

En sammenligning mellem udkast og endelig tekst bekræfter det indtryk, som de foregående undersøgelser har givet, nemlig at det var med udgangspunkt i rimbrevene fra I8I I, Grundtvig fandt den rimbrevsform, $\mathrm{i}$ hvilken han bedst kunne realisere sit menneskelige og digteriske selv. 